\title{
Front Matter: Volume 7824
}

, "Front Matter: Volume 7824," Proc. SPIE 7824, Remote Sensing for Agriculture, Ecosystems, and Hydrology XII, 782401 (8 November 2010); doi: 10.1117/12.881732

SPIE. Event: SPIE Remote Sensing, 2010, Toulouse, France 


\title{
PROCEEDINGS OF SPIE
}

\section{Remote Sensing for Agriculture, Ecosystems, and Hydrology XII}

\author{
Christopher M. U. Neale \\ Antonino Maltese \\ Editors
}

20-22 September 2010

Toulouse, France

Sponsored by

SPIE

Cooperating Organizations

European Association of Remote Sensing Companies (Belgium)

EOS-European Optical Society

CNES-Centre National d'Etudes Spatiales (France)

Deutsche Gesellschaft für Photogrammetrie, Fernerkundung, und Geoinformation e.V.

(Germany)

Remote Sensing and Photogrammetry Society (United Kingdom)

SFPT-Société Française de Photogrammétrie et de Télédétection (France)

Published by

SPIE

Volume 7824 
The papers included in this volume were part of the technical conference cited on the cover and title page. Papers were selected and subject to review by the editors and conference program committee. Some conference presentations may not be available for publication. The papers published in these proceedings reflect the work and thoughts of the authors and are published herein as submitted. The publisher is not responsible for the validity of the information or for any outcomes resulting from reliance thereon.

Please use the following format to cite material from this book:

Author(s), "Title of Paper," in Remote Sensing for Agriculture, Ecosystems, and Hydrology XII, edited by Christopher M. U. Neale, Antonino Maltese, Proceedings of SPIE Vol. 7824 (SPIE, Bellingham, WA, 2010) Article CID Number.

ISSN 0277-786X

ISBN 9780819483416

Published by

SPIE

P.O. Box 10, Bellingham, Washington 98227-0010 USA

Telephone +1 3606763290 (Pacific Time) · Fax +1 3606471445

SPIE.org

Copyright (C) 2010, Society of Photo-Optical Instrumentation Engineers

Copying of material in this book for internal or personal use, or for the internal or personal use of specific clients, beyond the fair use provisions granted by the U.S. Copyright Law is authorized by SPIE subject to payment of copying fees. The Transactional Reporting Service base fee for this volume is $\$ 18.00$ per article (or portion thereof), which should be paid directly to the Copyright Clearance Center (CCC), 222 Rosewood Drive, Danvers, MA 01923. Payment may also be made electronically through CCC Online at copyright.com. Other copying for republication, resale, advertising or promotion, or any form of systematic or multiple reproduction of any material in this book is prohibited except with permission in writing from the publisher. The CCC fee code is 0277-786X/10/\$18.00.

Printed in the United States of America.

Publication of record for individual papers is online in the SPIE Digital Library.

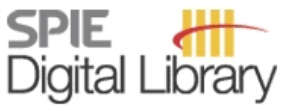

SPIEDigitalLibrary.org

Paper Numbering: Proceedings of SPIE follow an e-First publication model, with papers published first online and then in print and on CD-ROM. Papers are published as they are submitted and meet publication criteria. A unique, consistent, permanent citation identifier (CID) number is assigned to each article at the time of the first publication. Utilization of CIDs allows articles to be fully citable as soon they are published online, and connects the same identifier to all online, print, and electronic versions of the publication. SPIE uses a six-digit CID article numbering system in which:

- The first four digits correspond to the SPIE volume number.

- The last two digits indicate publication order within the volume using a Base 36 numbering system employing both numerals and letters. These two-number sets start with 00, 01, 02, 03, 04, $05,06,07,08,09,0 A, 0 B \ldots 0 Z$, followed by 10-1Z, 20-2Z, etc.

The CID number appears on each page of the manuscript. The complete citation is used on the first page, and an abbreviated version on subsequent pages. Numbers in the index correspond to the last two digits of the six-digit CID number. 


\title{
Contents
}

\author{
xi Conference Committee \\ xiii Conference Introduction \\ xv Session Introductions
}

\section{SESSION 1 LAND USE AND CHANGE DETECTION}

782402 Quantification and assessment of urban surface reflection ratios and their effect on aerosol retrieval using high spatial resolution LANDSAT retrievals [7824-01]

A. Picon, B. Madhavan, B. Gross, F. Moshary, S. Ahmed, The City College of New York (United States)

782403 Mapping of large irrigated areas in Central Asia using MODIS time series [7824-02] M. Machwitz, Univ. Würzburg (Germany); J. Bloethe, Univ. of Potsdam (Germany); D. Klein, C. Conrad, Univ. Würzburg (Germany); S. Dech, Univ. Würzburg (Germany) and Deutsches Zentrum für Luft- und Raumfahrt e.V. (Germany)

782404 Analysis of vegetation pasture climate response on Sahel region through 10 years of remotely sensed data [7824-03]

F. Nutini, CNR-IREA (Italy) and Univ. degli Studi di Milano (Italy); M. Boschetti, P. A. Brivio, CNR-IREA (Italy); E. Bartholomé, JRC-EC (Italy); A. Hoscilo, Univ. of Leicester (United Kingdom); D. Stroppiana, CNR-IREA (Italy); S. Bocchi, Univ. degli Studi di Milano (Italy)

\section{SESSION 2 BIOPHYSICAL VEGETATION VARIABLE RETRIEVAL}

782407 Preparatory analyses and development of algorithms for agricultural applications in the context of the EnMAP hyperspectral mission [7824-06]

K. Richter, T. Hank, W. Mauser, Ludwig-Maximilians-Univ. München (Germany)

782409 Statistical derivation of FPAR and LAI for irrigated cotton and rice in arid Uzbekistan by combining multi-temporal RapidEye data and ground measurements [7824-08]

A. Ehammer, S. Fritsch, C. Conrad, Julius-Maximilians-Univ. Würzburg (Germany); J. Lamers, Ctr. for Development Research (Germany); S. Dech, Julius-Maximilians-Univ. Würzburg (Germany) and Deutsches Zentrum für Luft- und Raumfahrt e.V. (Germany)

$7824 \mathrm{OA}$ Carbon partitioning as validation methods for crop yield and $\mathrm{CO}_{2}$ sequestration monitoring in Asia using a photosynthetic-sterility model [7824-09]

D. Kaneko, Remote Sensing Environmental Monitor, Inc. (Japan); P. Yang, Chinese Academy of Agricultural Sciences (China); T. Kumakura, Nagaoka Univ. of Technology (Japan)

7824 OB Inter-annual variation of NDVI over Korea Peninsula using harmonic analysis [7824-10] I.-H. Kim, K.-S. Han, K.-J. Pi, S.-J. Park, S.-I. Kim, Pukyong National Univ. (Korea, Republic of) 
7824 OC Mapping crop distribution in administrative districts of southwest Germany using multi-sensor remote sensing data [7824-11]

C. Conrad, A. Goessl, S. Lex, Julius-Maximilians-Univ. Würzburg (Germany); A. Metz, T. Esch, Deutsches Zentrum für Luft- und Raumfahrt e.V. (Germany); C. Konrad, European Institute for Energy Research (Germany); G. Goettlicher, EnBW Energie Baden-Württemberg AG (Germany); S. Dech, Deutsches Zentrum für Luft- und Raumfahrt e.V. (Germany)

7824 OD A case study on the early warning of agricultural drought [7824-90]

$X$. Zhang, China Agricultural Univ. (China) and Ningxia Institute of Meteorological Sciences (China); J. Fan, National Satellite Meteorological Ctr. (China); X. Yang, China Agricultural

Univ. (China); Y. Han, J. Wei, Ningxia Institute of Meteorological Sciences (China)

$7824 \mathrm{OE} \quad$ Airborne multispectral and thermal remote sensing for detecting the onset of crop stress caused by multiple factors [7824-13]

Y. Huang, S. J. Thomson, USDA Agricultural Research Service (United States)

\section{SESSION 4 JOINT SESSION WITH CONFERENCE 7826: SMOS}

7824 Ol Disaggregation as a top-down approach for evaluating $\mathbf{4 0} \mathbf{k m}$ resolution SMOS data using point-scale measurements: application to AACES-1 [7824-17] O. Merlin, Ctr. d'Etudes Spatiales de la Biosphère (France); C. Rüdiger, Monash Univ. (Australia); P. Richaume, A. Al Bitar, A. Mialon, Ctr. d'Etudes Spatiales de la Biosphère (France); J. P. Walker, Monash Univ. (Australia); Y. Kerr, Ctr. d'Etudes Spatiales de la Biosphère (France)

7824 OJ Event detection of hydrological processes with passive L-band data from SMOS [7824-18] A. Al Bitar, E. Jacquette, Y. Kerr, A. Mialon, F. Cabot, Ctr. d'Etudes Spatiales de la Biosphère (France); A. Quesney, Capgemini Sud (France); O. Merlin, P. Richaume, Ctr. d'Etudes Spatiales de la Biosphère (France)

7824 OK SMOS CATDS level 3 global products over land [7824-19]

E. Jacquette, A. Al Bitar, A. Mialon, Y. Kerr, Ctr. d'Etudes Spatiales de la Biosphère (France); A. Quesney, Capgemini Sud (France); F. Cabot, P. Richaume, Ctr. d'Etudes Spatiales de la Biosphère (France)

\section{SESSION $5 \quad$ LIDAR AND RADAR APPLICATIONS IN HYDROLOGY I}

$7824 \mathrm{OL} \quad$ Agricultural vegetation classification with SVM and polarimetric SAR data [7824-20] S. Daniel, CESBIO (France) and ONERA (France); S. Allain-Bailhache, Univ. de Rennes 1 (France); S. Angelliaume, P. Dubois-Fernandez, ONERA (France); E. Pottier, Univ. de Rennes 1 (France) 
$782400 \quad$ P-band SAR study of tropical forest in French Guiana [7824-24]

S. Daniel, CESBIO (France) and ONERA (France); P. Dubois-Fernandez, ONERA (France); T. Le Toan, CESBIO (France); J. Chave, Univ. Paul Sabatier (France); L. Blanc, CIRAD (French Polynesia); M. Davidson, European Space Research and Technology Ctr. (Netherlands)

7824 OP Evaluating TerraSAR-X for the identification of tillage occurrence over an agricultural area in Canada [7824-25]

A. M. Pacheco, H. McNairn, A. Merzouki, Agriculture and Agri-Food Canada (Canada)

$78240 Q \quad$ Tree crown detection in high resolution optical and lidar images of tropical forest [7824-27] J. Zhou, Univ. Montpellier 2 (France) and Ariana Research Group, INRIA (France); C. Proisy, IRD, UMR AMAP (France); X. Descombes, I. Hedhli, Ariana Research Group, INRIA (France); N. Barbier, IRD, UMR AMAP (France); J. Zerubia, Ariana Research Group, INRIA (France); J. P. Gastellu-Etchegorry, Univ. Paul Sabatier (France); P. Couteron, IRD, UMR AMAP (France)

7824 OR Strategies for lidar characterization of particulates from point and area sources [7824-28] M. D. Wojcik, K. D. Moore, R. S. Martin, Utah State Univ. (United States); J. Hatfield, National Lab. for the Agriculture and the Environment (United States)

\section{SESSION 7 ENERGY BALANCE AND EVAPOTRANSPIRATION}

7824 0X A critical analysis of three remote sensing-based actual evapotranspiration assessment methods over sparse crops agricultural areas [7824-33]

C. Cammalleri, G. Ciraolo, G. La Loggia, M. Minacapilli, Univ. degli Studi di Palermo (Italy)

\section{SESSION 8 PRECISION FARMING AND IRRIGATION MANAGEMENT}

$7824 \mathrm{OZ}$ A national system for monitoring the population of agricultural pests using an integrated approach of remote sensing data from in situ automated traps and satellite images [7824-35]

H. G. Diofantos, Cyprus Univ. of Technology (Cyprus); P. Panayiotis, P. Elias, CNE Technology Ltd. (Cyprus); G. K. Georgiou, Novatex Solutions Ltd. (Cyprus); T. Kyriacos, Cyprus Univ. of Technology (Cyprus)

782410 Spectral vegetation indices from field spectroscopy intended for evapotranspiration purposes for spring potatoes in Cyprus [7824-36]

P. Georgios, Cyprus Univ. of Technology (Cyprus) and Agricultural Research Institute of Cyprus (Greece); H. G. Diofantos, T. Kyriacos, Cyprus Univ. of Technology (Cyprus);

T. Leonidas, National Agricultural Research Foundation (Greece)

$782412 \quad$ Estimating leaf area index considering the crop geometry effection [7824-38]

W. Huang, National Engineering Research Ctr. for Information Technology in Agriculture (China) and The State Key Lab. of Remote Sensing Science (China); Y. Tang, R. Liu, G. Yang, $X$. Song, National Engineering Research Ctr. for Information Technology in Agriculture (China) 
782415 Study on the vegetation dynamic change using long time series of remote sensing data [7824-42]

J. Fan, China Meteorological Administration (China); X. Zhang, Institute of Ningxia Meteorological Sciences (China)

\section{SESSION 10 ESTUARINE AND COASTAL APPLICATIONS}

782419 Bathymetric estimation through principal components analysis using IKONOS-2 data [7824-47]

A. Teodoro, H. Gonçalves, J. Pais-Barbosa, Univ. do Porto (Portugal)

\section{SESSION 11 HYDROLOGICAL AND ECOSYSTEM MODELLING I}

7824 1B Integrated modeling of the water cycle in semi arid watersheds based on ground and satellite data: the SudMed project [7824-50]

V. Simonneaux, Ctr. d'Etudes Spatiales de la Biosphère (France); A. Abourida, A. Boudhar, A. Cheggour, Univ. Cadi Ayyad (Morocco); A. Chaponnière, Ctr. d'Etudes Spatiales de la Biosphère (France); B. Berjamy, Agence du Bassin Hydraulique du Tensift (Morocco); G. Boulet, Ctr. d'Etudes Spatiales de la Biosphère (France); A. Chehbouni, Univ. Cadi Ayyad (Morocco); L. Drapeau, B. Duchemin, Ctr. d'Etudes Spatiales de la Biosphère (France); S. Erraki, J. Ezzahar, Univ. Cadi Ayyad (Morocco); R. Escadafal, Ctr. d'Etudes Spatiales de la Biosphère (France); N. Guemouria, L. Hanich, Cadi Ayyad Univ. (Morocco); L. Jarlan, Ctr. d'Etudes Spatiales de la Biosphère (France); H. Kharrou, Office Régional de Mise en Valeur Agricole du Haouz (Morocco); S. Khabba, Cadi Ayyad Univ. (Morocco); M. Le Page, S. Mangiarotti, O. Merlin, B. Mougenot, Ctr. d'Etudes Spatiales de la Biosphère (France); A. Mokssit, A. Ouldbba, Direction de la Météorologie Nationale (Morocco); A. Chehbouni, Ctr. d'Etudes Spatiales de la Biosphère (France)

7824 1C Contribution of earth observation data to Congo River basin hydrology understanding [7824-51]

M. Boschetti, CNR-IREA (Italy); F. Nutini, CNR-IREA (Italy) and Univ. of Milano (Italy);

P. A. Brivio, CNR-IREA (Italy); E. Bartholome, JRC-EC (Italy); D. Stroppiana, CNR-IREA (Italy)

7824 1D Revising the land cover and use classification of northern areas for climate modeling [7824-52]

M. Törmä, Finnish Environment Institute (Finland); A. N. Arslan, Finnish Meteorological Institute (Finland); S. Hatunen, P. Härmä, Finnish Environment Institute (Finland); T. Markkanen, J. Susiluoto, J. Pulliainen, Finnish Meteorological Institute (Finland)

$7824 \mathrm{IF}$ Analysis of a meso- $B$ scale convective system during a brief torrential rain event in northeast China [7824-54]

M. Yuan, Provincial Meteorological Observatory of Heilongjiang (China) and Nanjing Univ. of Information Science and Technology (China); Z. Li, X. Zhang, National Meteorological Ctr. of China (China); N. Xu, Heilongjiang Meteorological Administration (China) 
7824 IG A thermal inertia model for soil water content retrieval using thermal and multispectral images [7824-55]

A. Maltese, M. Minacapilli, C. Cammalleri, G. Ciraolo, F. D'Asaro, Univ. degli Studi di Palermo (Italy)

782411 Remote sensing indicators to identify low and moderately salt-affected soils based on MODIS Terra and geochemical data [7824-57]

M. Bouaziz, J. Matschullat, R. Gloaguen, Technische Univ. Bergakademie Freiberg

(Germany)

7824 1K A physical model for LAI retrieval: directional second derivative of canopy spectra [7824-59]

B. Y. Yan, W. J. Fan, X. R. Xu, Peking Univ. (China); X. C. Liu, Nanjing Univ. (China); Y. K. Cui, Peking Univ. (China)

\section{POSTER SESSION: ENERGY BALANCE AND EVAPOTRANSPIRATION}

$7824 \mathrm{lL} \quad$ Modeling the radiation transfer of discontinuous canopies: results for gap probability and single-scattering contribution [7824-62]

F. Zhao, K. Zou, H. Shang, Z. Ji, H. Zhao, Beijing Univ. of Aeronautics and Astronautics (China); W. Huang, C. Li, National Engineering Research Ctr. for Information Technology in

Agriculture (China)

7824 IM In situ hyperspectral data analysis for coverage estimation of submerged plant Vallisneria spiralis in Hangzhou Bay wetland [7824-63]

Q. Cheng, X. Wu, Zhejiang Gongshang Univ. (China)

$78241 \mathrm{~N} \quad$ Estimation of chlorophyll a and total suspended matter concentration using Quickbird image and in situ spectral reflectance in Hangzhou Bay, China [7824-64]

X. WU, Q. Cheng, Zhejiang Gongshang Univ. (China)

782410 Dynamic threshholds for land surface change detection using image differencing [7824-65]

S. Kim, K.-S. Han, I.-H. Kim, J.-M. Yeom, K.-J. Pi, Pukyong National Univ. (Korea, Republic of)

7824 IP Analysis of the spectral response of Tamarix spp vegetation to the soil salinity based on ground spectral measurements [7824-66]

G. Jiapaer, X. Chen, A. Bao, Xinjiang Institute of Ecology and Geography (China)

\section{POSTER SESSION: PRECISION FARMING AND IRRIGATION MANAGEMENT}

7824 1Q Polarimetric millimetre wave SAR for precision farming applications [7824-67]

H. Essen, D. Nüßler, C. Krebs, H. Schimpf, W. Johannes, A. Wahlen, Fraunhofer Institute for High Frequency Physics and Radar Techniques (Germany) 
7824 is MODIS estimates of annual evapotranspiration of irrigated crops in the Nile delta based on the FAO method: application to the Nile river budget [7824-69]

V. Simonneaux, Ctr. d'Etudes Spatiales de la Biosphère (France); M. A. A. Abdrabbo,

S. M. Saleh, M. K. Hassanein, Central Lab. for Agricultural Climate (Egypt); A. F. Abou-Hadid, Agricultural Research Ctr. (Egypt); A. Chehbouni, Ctr. d'Etudes Spatiales de la Biosphère (France)

\section{POSTER SESSION: LAND USE AND CHANGE DETECTION}

7824 IT Use of satellite remote sensing for analysis of environmental impacts due to urbanization [7824-70]

M. A. Zoran, R. S. Savastru, D. M. Savastru, S. I. Miclos, M. N. Tautan, L. Baschir, National Institute of R\&D for Optoelectronics (Romania)

$78241 \mathrm{U}$ Research on IKONOS shadow extraction in urban region based on the principal component fusion information distort [7824-72]

C. Li, J. Wang, Q. Wang, W. Huang, X. Xu, China National Engineer Research Ctr. for Information Technology in Agriculture (China)

7824 1X Summer-time thermal environment characteristics in central Korea using Landsat TM data [7824-75]

J.-K. Park, J.-H. Park, S. Na, Chungbuk National Univ. (Korea, Republic of)

SESSION 15 POSTER SESSION: ESTUARINE AND COASTAL APPLICATIONS

7824 IY Spectroradiometric characteristics of inland water bodies infestated by Oscillatoria Rubescens algae [7824-76]

G. Ciraolo, G. La Loggia, A. Maltese, Univ. degli Studi di Palermo (Italy)

$7824 \mathrm{lZ}$ Coupling a hydro-maritime model and remotely sensed techniques to assess the shoreline positioning uncertainty: the Marsala coast study case [7824-78]

G. Manno, C. Lo Re, G. Ciraolo, A. Maltese, Univ. degli Studi di Palermo (Italy)

\section{POSTER SESSION: HYDROLOGICAL AND ECOSYSTEM MODELLING}

782421 Assessment of effect of climate change on agricultural and ecological environments in northeast China with countermeasures and suggestions [7824-81]

N. XU, Nanjing Univ. of Information Science and Technology (China) and Heilongjiang Meteorological Administration (China); P. Guo, Nanjing Univ. of Information Science and Technology (China); Z. Xiao, National Climate Ctr. (China); M. Yuan, Heilongjiang Provincial Meteorological Observatory (China)

782422 Numerical simulation of the light field in the hydrologic system using in situ inherent optical properties and matrix-operator method [7824-82]

B. Tao, The Second Institute of Oceanography, SOA (China), Shanghai Institute of Technical Physics (China), and Graduate School of Chinese Academy of Sciences (China); Z. Mao, D. Wang, J. Chen, The Second Institute of Oceanography, SOA (China); B. Jin, PLA Univ. of Science and Technology (China) 
782423 Integrated GIS/AHP-based flood disaster risk assessment and zonation: a case study of Henan Province, China [7824-83]

J. Li, H. Chen, Z. Liu, C. Zou, Henan Institute of Meteorological Science (China) and Key Lab. of Agrometeorological Safeguard and Applied Technique (China)

782425 Surface soil humidity retrieval using remote sensing techniques: a triangle method validation [7824-85]

A. Maltese, C. Cammalleri, F. Capodici, G. Ciraolo, G. La Loggia, Univ. degli Studi di Palermo (Italy)

\section{SESSION 16 LIDAR AND RADAR APPLICATIONS IN HYDROLOGY}

782426 A field experiment over wheat with ground-based microwave radiometer [7824-23]

S. Wu, National Satellite Meteorological Ctr. (China); S. Zhao, Beijing Normal Univ. (China)

782427 Surface soil humidity retrieval by means of a semi-empirical coupled SAR model [7824-86] F. Capodici, G. La Loggia, Univ. degli Studi di Palermo (Italy); G. D'Urso, Univ. degli Studi di Napoli Federico II (Italy); A. Maltese, G. Ciraolo, Univ. degli Studi di Palermo (Italy)

\section{SESSION 17 VEGETATION AND CROP MONITORING}

$782428 \quad$ Estimating growth height of winter wheat with remote sensing [7824-40]

X. Xu, J. Wang, C. Li, X. Song, W. Huang, National Engineering Research Ctr. for Information Technology in Agriculture (China)

782429 Satellite and in situ monitoring data used for modeling of forest vegetation reflectance [7824-87]

M. A. Zoran, R. S. Savastru, D. M. Savastru, S. I. Miclos, M. N. Tautan, L. Baschir, National Institute of R\&D for Optoelectronics (Romania)

7824 2A A high-resolution index for vegetation extraction in IKONOS images [7824-88] M. Chikr El-Mezouar, Univ. de Djillali Liabes (Algeria) and Institut National des Sciences Appliquées de Rennes (France); N. Taleb, Univ. de Djillali Liabes (Algeria); K. Kpalma, J. Ronsin, Institut National des Sciences Appliquées de Rennes (France)

7824 2B Sunshine duration derived from FY-2 data in North China [7824-89]

M. Zhang, J. Fan, G. Li, J. Liu, China Meteorological Administration (China)

$78242 \mathrm{E} \quad$ Estimation of vegetation fraction in arid areas using ALOS imagery [7824-93] A. A. Matkan, R. Darvishzadeh, A. Hosseiniasl, M. Ebrahimi, Shahid Beheshti Univ. (Iran, Islamic Republic of)

$78242 \mathrm{~F}$ Spatio-temporal variations in cropland phenology in North China over the past 20 years [7824-94]

M. Zhang, J. Fan, G. Li, J. Liu, China Meteorological Administration (China) 
$78242 \mathrm{G}$ Winter wheat growth and grain protein uniformity monitoring through remotely sensed data [7824-95]

X. Song, National Engineering Research Ctr. for Information Technology in Agriculture (China); J. Wang, National Engineering Research Ctr. for Information Technology in Agriculture (China) and Key Lab. for Information Technologies in Agriculture (China); W. Huang, National Engineering Research Ctr. for Information Technology in Agriculture (China)

$78242 \mathrm{H} \quad$ Quantification of the relationship between Normalized Difference Vegetation Index (NDVI) and Land Surface Temperature (LST) in arable land [7824-96]

S.-I. Na, J.-H. Park, J.-K. Park, Chungbuk National Univ. (Korea, Republic of)

$78242 \mathrm{~K}$ The analysis and application of satellite-airborne-in situ observation synchronized test data in Henan province [7824-99]

H. Chen, Key Lab. of Agrometeorological Safeguard and Applied Technique (China) and Henan Institute of Meteorological Science (China); H. Zhang, Key Lab. of

Agrometeorological Safeguard and Applied Technique (China), Henan Institute of Meteorological Science (China), and Xinxiang Meteorological Bureau (China); Z. Liu, Key Lab. of Agrometeorological Safeguard and Applied Technique (China) and Henan Institute of Meteorological Science (China)

$78242 \mathrm{~L}$ The review of dynamic monitoring technology for crop growth [7824-100]

$\mathrm{H}$. Zhang, Key Lab. of Agro-meteorological Safeguard and Applied Technique (China) and Xinxiang Meteorological Bureau (China); H. Chen, C. Zou, W. Yu, Key Lab. of Agro-meteorological Safeguard and Applied Technique (China)

$78242 \mathrm{M}$ The analysis of winter wheat dynamic growth based on the data of MODIS coupled with in situ observation [7824-101]

H. Zhang, Key Lab. of Agro-meteorological Safeguard and Applied Technique (China) and Xinxiang Meteorological Bureau (China); H. Chen, Key Lab. of Agro-meteorological Safeguard and Applied Technique (China)

$78242 \mathrm{~N} \quad$ Study on the assessment of flood disaster on summer maize based on GIS and RS technology [7824-102]

Z. Liu, H. Chen, Z. Du, Henan Institute of Meteorological Science (China) and Henan Key Lab. of Agrometeorological Ensuring and Applied Technique (China); W. Fang, ZhuMaDian Meteorological Bureau (China); J. Li, L. Shi, Henan Institute of Meteorological Science (China) and Henan Key Lab. of Agrometeorological Ensuring and Applied Technique (China)

Author Index 


\title{
Conference Committee
}

\author{
Symposium Chair
}

Steven P. Neeck, NASA Headquarters (United States)

Symposium Cochair

Karin Stein, Fraunhofer-Institut für Optronik, Systemtechnik und

Bildauswertung (Germany)

Conference Chairs

Christopher M. U. Neale, Utah State University (United States)

Antonino Maltese, Università degli Studi di Palermo (Italy)

\section{Conference Cochair}

Katja Richter, Ludwig-Maximilians-Universität München (Germany)

\section{Program Committee}

Guido D'Urso, Università degli Studi di Napoli Federico II (Italy)

Richard A. M. de Jeu, Vrije Universiteit Amsterdam (Netherlands)

Goffredo La Loggia, Università degli Studi di Palermo (Italy)

Francesco Vuolo, University of Southampton (United Kingdom)

Session Chairs

1 Land Use and Change Detection

Antonino Maltese, Università degli Studi di Palermo (Italy)

2 Biophysical Vegetation Variable Retrieval

Katja Richter, Ludwig-Maximilians-Universität München (Germany)

3 Drought and Crop Monitoring

Francesco Vuolo, University of Southampton (United Kingdom)

4 SMOS: Joint Session with Conference 7826

Antonino Maltese, Università degli Studi di Palermo (Italy)

Yann H. Kerr, Centre d'Etudes Spatiales de la Biosphère (France)

$5 \quad$ Lidar and Radar Applications in Hydrology I

Antonino Maltese, Università degli Studi di Palermo (Italy) 
6 Lidar and Radar Applications in Hydrology II

Antonino Maltese, Università degli Studi di Palermo (Italy)

$7 \quad$ Energy Balance and Evapotranspiration

Antonino Maltese, Università degli Studi di Palermo (Italy)

8 Precision Farming and Irrigation Management

Katja Richter, Ludwig-Maximilians-Universität München (Germany)

$9 \quad$ Vegetation and Crop Monitoring

Katja Richter, Ludwig-Maximilians-Universität München (Germany)

10 Estuarine and Coastal Applications

Antonino Maltese, Università degli Studi di Palermo (Italy)

11 Hydrological and Ecosystem Modelling I

Goffredo La Loggia, Università degli Studi di Palermo (Italy)

12 Hydrological and Ecosystem Modelling II

Goffredo La Loggia, Università degli Studi di Palermo (Italy) 


\section{Introduction}

This proceedings volume contains papers presented during the conference on Remote Sensing for Agriculture, Ecosystems, and Hydrology XII. The conference was part of the 17th International Symposium on Remote Sensing sponsored by SPIE. The symposium was held at the Centre de Congrès Pierre Baudis, Toulouse, France, from the 20th to 23th of September 2010.

The conference is dedicated to providing rapid dissemination of scientific and technical information, and attracted scientists and professionals from throughout Europe, Africa, Asia, and the Americas. Approximately 50 oral and 25 poster presentations were given, covering a broad range of topics in the field of remote sensing applications in environmental science.

The program was organized according to major themes, with 10 sessions on Agriculture: Land Use and Change Detection, Biophysical Vegetation Variable Retrieval, Drought and Crop Monitoring, Precision Farming and Irrigation Management, Vegetation and Crop monitoring; Ecosystems: Estuarine and Coastal Applications, Hydrology: Hydrological and Ecosystem Modelling (2), Lidar and Radar Applications in Hydrology (2), Energy Balance and Evapotranspiration and a SMOS Joint Session with with Conference 7826: Sensors, Systems, and NextGeneration Satellites. The poster presentations also had good representation from the above mentioned themes. The presentations described both fundamental and applications-based research activities from modelling, to laboratory and field experiments, to operational applications. The oral program also includes three invited speeches: Yann H. Kerr Kerr of Ctr. d'Etudes Spatiales de la Biosphère gave a speech on the subject "SMOS: from concept to operations and from operation to the next generation"; Frédéric Baret of Centre Inra PACA Recherches Avignon (Environnement Méditerranéen et Modélisation des AgroHydrosystèmes) gave a speech on the subject "'Estimation of vegetation biophysical variables from remote sensing observations" within the session Biophysical Vegetation Variable Retrieval; John Prueger of USDA Agricultural Research Service (National Soil Tilth Lab) gave a speech on the subject "Surface flux processes and evolution of characteristic eddy scales over dry land and irrigated surfaces in response to saturation deficit advection"; A short report on the SMOS Joint Session and introductory overviews of the state of the art and perspective of the invited speeches are reported afterwards.

We extend our thanks to the Session chairs (Katja Richter of Ludwig-MaximiliansUniv. München and Francesco Vuolo of Univ. of Southampton and Goffredo La Loggia of Univ. degli Studi di Palermo and Yann H. Kerr of Ctr. d'Etudes Spatiales de la Biosphère), and to the presenters for their efforts and to the participants for their insightful questions and discussions. Special thanks are also due to the host city for the excellent venue and to the SPIE organizational staff for their support 
prior to, during, and after the symposium. We look forward to an even more successful conference in 2011.

Christopher Neale Antonino Maltese 